\title{
The European Society of Neuroradiology
}

The European Society of Neuroradiology (ESNR) was founded on September 5, 1969 during a meeting which took place in Colmar, France, upon the initiative of Drs Jean-Paul Braun (Colmar) and Auguste Wackenheim (Strasbourg) and under the guidance and support of Professor George B. Ziedses des Plantes (Amsterdam). The following purposes of the Society were unanimously adopted by the 68 Founding Members:

1. To promote Neuroradiology by appropriate means.

2. To co-ordinate work and documents in Neuroradiology and to assure their diffusion throughout the countries of Europe.

3. To co-ordinate the relationships between General Radiology and the Clinical Neurosciences.

4. To contribute toward unified methods of teaching Neuroradiology and unified standards for training and certification in Neuroradiology.

5. To promote and co-ordinate relationships among the European National Neuroradiological Societies and to promote the foundation of National Neuroradiological Societies.

6. To form European research teams to deal with specific neuroradiological questions.

\section{Founding Members of the ESNR}

P. Amundsen, Norway

P. Andersen, Denmark

H. Backmund, Germany

K. Bergström, Sweden

V. Bernasconi, Italy

A.S. Bligh, UK

G. Bonte, France

J. Bories, France

G. Bradac, Germany

J.P. Braun, France

P. Buffard, France

J.W.D. Bull, UK

E.H. Burrows, UK

A. Calabrò, Italy

R. Chrzanowski, Poland

G. Cornélis, Belgium

S. Cronqvist, Sweden

K. Decker, Germany

P. Dettori, Italy

R. Djindjian, France

A. Donaldson, UK

G. du Boulay, UK

J. Duquesnel, France
$\mathrm{Ph}$. Engel, France

L. Escudero, Spain

H. Fischgold, France

T. Greitz, Sweden

G. Gryspeerdt, UK

H. Hacker, Germany

D.T. Hawkins, UK

R. Hoare, UK

P. Huber, Switzerland

H.H. Jacobsen, Denmark

J. Jeanmart, Belgium

J. Jirout, former Czechoslovakia

E.M. Klausberger, Austria

J. Legré, France

B. Liliequist, Sweden

E. Lindgren, Sweden

G. Lombardi, Italy

J. Metzger, France

P. Moxon, UK

D. Müller, Germany

R. Oberson, Switzerland

A. Passerini, Italy

L. Penning, The Netherlands
J. Petrov, Germany

L. Picard, France

P. Potthoff, Germay

L. Psenner, Austria

R. Reid, UK

J. Roulleau, France

M. Roth, former Czechoslovakia

G. Ruggiero, Italy

G. Salamon, France

W. Shepherd, UK

J. Simon, France

F. Smaltino, Italy

J. Solé-Llenas, Spain

A. Tänzer, Germany

A. Thibaut, Belgium

H. Vogelsang, Germany

A. Wackenheim, France

S. Wende, Germany

G. Westberg, Sweden

I. Wickholm, Sweden

O. Wiedermann, Germany

G.B. Ziedses des Plantes, The Netherlands

Full Membership in the ESNR is open to medical practitioners who have accomplished at least two years formal training in Neuroradiology and who spend at least half of their working time in the practice of Neuroradiology in a European country. Other membership categories include Associate, Corresponding, Honorary, Emeritus and Corporate Membership. There are presently nearly 600 members in all categories, including about 400 active Neuroradiologists in all European countries as Full Members. 


\section{Board of the ESNR}

\section{Executive Committee}

\section{President \\ Vice-President \\ Past-President \\ Secretary General \\ Treasurer \\ Chairman NDs Council \\ Members at Large \\ Director ECNR ex-officio}

Jordi Ruscalleda

Martin Schumacher

Olof Flodmark

Guido Wilms

Othmar Schubiger

Massimo Gallucci

Augusto Goulão, Paul Parizel, Alex Rovira Cañellas

Ernst Wilhelm Radü

\section{National Delegates}

$\begin{array}{lll}\text { Austria } & \text { G. Klein } & \text { Luxembourg } \\ \text { Belgium } & \text { J. Casselman } & \text { The Netherlands } \\ \text { Croatia } & \text { S. Jancovic } & \text { Norway } \\ \text { Czech Republic } & \text { P. Krupa } & \text { Poland } \\ \text { Denmark } & & \text { Portugal } \\ \text { Finland } & \text { R. Vanninen } & \text { Serbia and Montenegro } \\ \text { France } & \text { P. Lasjaunias } & \text { Slovenia } \\ \text { Germany } & \text { R. von Kummer } & \text { Spain } \\ \text { Greece } & \text { A. Gouliamos } & \text { Sweden } \\ \text { Hungary } & \text { P. Barsi } & \text { Switzerland } \\ \text { Ireland } & \text { P. Brennan } & \text { Turkey } \\ \text { Italy } & \text { M. Gallucci } & \text { United Kingdom } \\ \text { Latvia } & \text { G. Krumina } & \end{array}$

G. Dooms

J. Wilmink

S. J. Bakke

J. Walecki

N. Canto-Moreira

A. Jasovic

J. Knific

L. Nombela

B. Berthelsen

E. W. Radue

E. T. Tali

Ch. Romanowski

\section{Honorary Members of the ESNR}

Giovanni di Chiro, USA (1989)

T. Hans Newton, USA (1989)

Juan M. Taveras, USA (1989)

Jacqueline Vignaud, France (1993)

Derek C. Harwood-Nash, Canada (1993)

Torgny Greitz, Sweden (1994)

Yutaka Kuru, Japan (1994)

Jan Jirout, Czech Rep. (1994)

Jean Paul Braun, France (1995)

Peter Huber, Switzelarnd (1995)

Georges Salamon, France (1995)
Antonio Sicuro, Italy (1995)

Gerard M. Debrun, U.S.A. (1997)

Paulo A. Mendo, Portugal (1997)

Hans Hacker, Germany (1999)

Thomas P. Naidich, USA (1999)

Juan Solé Llenas, Spain (1999)

Brian Kendall (2001)

Robert Zimmerman (2001)

Lourens Penning (2002)

These pioneers in Neuroradiology have significantly furthered the development of Neuroradiology, increased the prestige of the speciality and made important contributions to the scientific and academic life of European institutions.

\section{Past Presidents}

George B. Ziedses des Plantes, Amsterdam

James W.D. Bull, London

Giovanni Ruggiero, Bologna

Per Amundsen, Oslo

Auguste Wackenheim, Strasbourg

George du Boulay, London

Sten Cronqvist, Lund

Jean Paul Braun, Colmar

Ugo Salvolini, Ancona

Pierre Lasjaunias, Paris

Claude Manelfe, Toulouse

Olof Flodmark

\section{Honorary Presidents}

1969-1972

1972-1975

1975-1978

1978-1981

1981-1984

1984-1987

1987-1990

1990-1993

1993-1996

1996-1998

1998-2000

2000-2004
George B. Ziedses des Plantes

Giovanni Ruggiero

Auguste Wackenheim

George du Boulay

Sten Cronqvist

Jean Paul Braun 


\section{Committees of the ESNR}

\section{Standing Committees}

Technical Committees

\section{Rules}

J. Byrne (Chair)

E. A. Cabanis

A. Lilja

v. Kummer

J. Reul

\author{
Membership \\ B. Gomez-Anson \\ Audit \\ E.-M. Larsson (Chair) \\ P. Parizel \\ I. Szikora
}

\section{Scientific Committees}

Publication

H. R. Jäger (Chair)

M. Gallucci

P. Sundgren

M. Thurner

J. Byrne

\section{Scientific Programme}

D. Ruefenacht

\section{Scientific Award}

B. Appel (Chair)

M. Hourihan

P. Nakstad

\section{Education-EBNR}

O. Flodmark (Chair)

P. Lasjaunias

M. Leonardi

O. Schubiger

E.W. Radue

P. Griffiths

T. Krings

P. Parizel

A. Rovira
Sub-speciality Committees

\section{Interventional Neuroradiology}

A. Goulão (Chair)

P. Ferro Vilela

M. Muto

R. Sellar

T. Yousry

Paediatric Neuroradiology

P. Tortori Donati (Chair)

P. Demaerel

N. Girard

E. Martin-Fiori

Ch. Romanowski

Head and Neck Neuroradiology

A. Valavanis (Chair)

Ph. Anslow

J. Casselman

M. De Juan Delago

L. van den Hauwe
Ad Hoc Committees

European Affairs and NR Specialization / UEMS

P. Lasjaunias

Symposium Neuroradiologicum

L. Picard (Chair)

M. Leonardi

European Exchange Programme M. Schumacher (Chair)

J. Byrne

J. Ruscalleda

R. von Kummer

T. Yousry 


\section{Past Officers}

1969-1972

President

Vice-President

Secretary General

Assistant Secretary

1972-1975

President

Vice-President

Secretary General

Assistant Secretary

1975-1978

President

Vice-President

Secretary General

Assistant Secretary

1978-1981

President

Vice-President

Secretary General Assistant Secretary

1981-1984

President

Vice-President

Secretary General

Assistant Secretary

Treasurer

1984-1987

President

Vice-President

Secretary General

Assistant Secretary

Treasurer

1987-1990

President

Vice-President

Secretary General

Assistant Secretary

Treasurer
George B. Ziedses des

Plantes, Amsterdam

James W. Bull, London

Auguste Wackenheim,

Strasbourg

Jean Paul Braun, Colmar

James W. Bull, London

Giovanni Ruggiero,

Bologna

Auguste Wackenheim,

Strasbourg

Jean Paul Braun, Colmar

Giovanni Ruggiero,

Bologna

Per Amundsen, Oslo

Auguste Wackenheim,

Strasbourg

Jean Paul Braun, Colmar

Per Amundsen, Oslo

Auguste Wackenheim, Strasbourg

Jean Paul Braun, Colmar

Peter Huber, Bern

Auguste Wackenheim, Strasbourg

George du Boulay, London Jean Paul Braun, Colmar Uwe Piepgras, Homburg

Peter Huber, Bern

George du Boulay, London

Sten Cronqvist, Lund

Jean Paul Braun, Colmar

Uwe Piepgras, Homburg

Peter Huber, Bern

Sten Cronqvist, Lund

Jean Paul Braun, Colmar

Uwe Piepgras, Homburg

Ugo Salvolini, Ancona

Peter Huber, Bern
1990-1993

President

Vice-President

Secretary General

Assistant Secretary

Treasurer

1993-1996

President

Vice-President

Secretary General

Assistant Secretary

Treasurer

1996-1998

President

Vice-President

Past-President

Secretary General

Treasurer

Counsellors

Chairman NDs Council

1998-2000

President

Vice-President

Past-President

Secretary General

Treasurer

Counsellors

Chairman NDs Council

2000-2004

President

Vice-President

Past-President

Secretary General

Treasurer

Chairman NDs Council

Members at Large:

Elna-Marie Larsson, Per Hj. Nakstad
Jean Paul Braun, Colmar

Uwe Piepgras, Homburg

Anton Valavanis, Zürich

Pierre Lasjaunias, Paris

Peter Huber, Bern

Ugo Salvolini, Ancona

Danielle Balériaux, Bruxelles

Marco Leonardi, Milano

Armin Thron, Aachen

Othmar Schubiger, Zürich

Pierre Lasjaunias, Paris

Claude Manelfe, Toulouse

Ugo Salvolini, Ancona

Marco Leonardi, Bologna

Othmar Schubiger, Zurich

Olof Flodmark, Stockholm

Ivan Moseley

Claude Manelfe, Toulouse

Olof Flodmark, Stockholm

Pierre Lasjaunias, Paris

Marco Leonardi, Bologna

Othmar Schubiger, Zurich

C. Andreula

M. Schumacher

Olof Flodmark

Luc Picard - Jordi Ruscalleda

Claude Manelfe

Marco Leonardi

Othmar Schubiger

Martin Schumacher

Cosma Andreula, 


\section{Lucien Appel Prize of the ESNR}

\section{Rules for participation}

\section{Article 1 :}

The "Lucien Appel Prize of the ESNR" will reward the achievements of a young neuroradiologist under the age of 40 years. This Scientific Award is open to all candidates, independent of nationality, member or non-member of the ESNR.

Article 2 :

The Prize, to the amount of 4.000 Euro, awarded during each Annual Congress of the ESNR or Neuroradiological Symposium, includes full coverage of the guest registration fee for this Annual Congress.

Article 3 :

The Candidate has to be the author of at least three papers or an original work in the field of Neuroradiology. This work, recently published in a scientific journal or still unpublished, may not have received any prize.

The Contest is open for application each year before May $1^{\text {st. }}$

Article 4 :

The submission must be sent as a manuscript written in English as well as in an electronic format (3.5' floppy disc, ZIP 100 or CD-ROM, all PC formatted).

Original works in other languages must be submitted together with a translation into English. The submission, supplied in eight copies, shall also include three copies of the extensive Curriculum Vitae of the author.

By submitting the work to the competition the author agrees, if declared the winner, to present the work at the next ESNR Annual Congress.

Article 5 :

A Scientific Jury will judge the papers. This Jury, composed of the Chairman of the Scientific Committee and two members, will each year be enlarged by four International Specialists in Neuroradiology.

Article 6 :

The Scientific Award Committee, leaning on this advice, will designate the Laureate before July the $1^{\text {st }}$. If the Committee decides that no Candidate meets the qualification standards, no Prize will be awarded.

Article 7 :

All Candidates will be notified in writing of the results of the vote. The Laureate will be invited to present his / her work in a 15 minutes oral presentation during the Annual Congress.

The Award and the Laureate will be announced to various European and International Journals for Neuroradiology. A winning and still unpublished paper will appear in "Neuroradiology".

Article 8 :

All possible problems concerning the validity of Candidates and/or problems regarding the awarding of the Prize itself will be dealed with exclusively by the Scientific Award Committee.

Article 9 :

Candidateship implies acceptance of the rules.

The Award winners of the Lucien Appel Prize of the ESNR:

2005 M. Bendszuz

2006 L.S. Politi 
The Award winners of the ESNR Scientific Award (1970-2004) include:

\begin{tabular}{|c|c|c|c|}
\hline 1970 & C. Manelfe (France) & & \\
\hline 1971 & M. Corrales (Chile) & 1988 & A. Biondi (Italy) \\
\hline \multirow[t]{3}{*}{1972} & M. Megret (Switzerland) & & J. Moret (France) \\
\hline & J.J. Merland (France) & & P. Parizel (Belgium) \\
\hline & M. Michotey (France) & & G. Schroth (Germany) \\
\hline \multirow[t]{2}{*}{1975} & I. Moseley (United Kingdom) & 1989 & C. Debusche (France) \\
\hline & G. Scialfa (Italy) & 1991 & G. Isensee (Germany) \\
\hline 1977 & D. Lardé (France) & & K.G. Terbrugge (Canada) \\
\hline \multirow[t]{3}{*}{1982} & S. Bockenheimer (Germany) & 1992 & M. Forsting (Germany) \\
\hline & K. Kretschmar (Germany) & & M. Martinez (Spain) \\
\hline & P. Lasjaunias (France) & & N. Anzalone (Italy) \\
\hline \multirow[t]{3}{*}{1983} & R. Aaslid (Norway) & 1993 & L. Van den Hauwe (Belgium) \\
\hline & J.L. Burguet (France) & & K.E.W. Eberhardt (Germany) \\
\hline & A. Valavanis (Switzerland) & & F. Barkhof (United Kingdom) \\
\hline \multirow[t]{3}{*}{1985} & J. Barckley (United Kingdom) & & N. Colombo (Italy) \\
\hline & P. Parizel (Belgium) & 1994 & Z. Patay (Hungary) \\
\hline & D. Rüfenacht (Switzerland) & & S. Lehericy (France) \\
\hline \multirow[t]{3}{*}{1986} & A. Beltramello (Italy) & 1999 & I. Burtscher (Sweden) \\
\hline & J. Chiras (France) & 2000 & M. Knauth (Germany) \\
\hline & M. Mosskin (Sweden) & 2001 & G. Polonara (Italy) \\
\hline \multirow[t]{3}{*}{1987} & F. Koschorek (Germany) & 2002 & Ph. White (UK) \\
\hline & N. Martin (France) & 2003 & L. Raffi \\
\hline & F. Triulzi (Italy) & 2004 & T. Krings \\
\hline
\end{tabular}

If you require further information, please contact:

\section{ESNR Secretary General}

Prof. Guido Wilms

Afdeling Radiologie

UZ Gasthuisberg

Herestraat 49

B-3000 Leuven

Tel. nr. + 3216343781

Fax nr. + 3216343765

E-mail: Guido.Wilms@uz.kuleuven.ac.be

ESNR Web-site on the Internet:

\section{ESNR Central Office}

c/o AISC \& MGR

AIM Group

Congress Division

Via Ripamonti, 129

I-20141 Milano

Tel. nr . + 3902566011

Fax nr. + 390256609045

E-mail: esnr@aimgroup.it

http://www.esnr.org 


\section{Congress of the ESNR}

The European Society of Neuroradiology holds each year a scientific congress at a place and date designated by the Executive Committee. The business meeting (General Assembly) of the Society is held in conjunction with this annual scientific congress. Since its creation in 1969, the ESNR has organised 31 scientific congresses. In recognition of the importance of the Symposium Neuroradiologicum, which is held every four years, no scientific congress of the ESNR was held in the year of the Symposium.

\section{Past Congresses}

\section{Congress}

September 6, 1969

Colmar, France

Presidents: J.P. Braun and

A. Wackenheim

\section{Congress}

September 24-25, 1971

London, United Kingdom

President: J.D.W. Bull

\section{Congress}

August 23-24, 1972

Bologna, Italy

President: G. Ruggiero

\section{Congress}

September 28-29, 1973

Frankfurt, Germany

President: H. Hacker

\section{Congress}

September 4-6, 1975

Gello, Norway

President: P. Amundsen

\section{Congress}

September 16-18, 1976

Dijon, France

President: J. Bories

\section{Congress}

September 9-10, 1977

Barcelona, Spain

President: M. Rovira

\section{Congress}

September 7-8, 1979

Strasbourg, France

President: A. Wackenheim

\section{Congress}

September 12-13, 1980

Brussels, Belgium

President: G. Cornelis

\section{$\mathrm{X}$ Congress}

September 25-26, 1981

Milan, Italy

President: A. Passerini

\section{Congress}

September 15-17, 1983

Bern, Switzerland

President: H. Huber

\section{Congress}

September 27-29, 1984

Prague, Czechoslovakia

President: J. Jirout

\section{Congress}

September 11-15, 1985

Amsterdam, The Netherlands

President: J. Valk

\section{Congress}

September 8-12, 1987

Udine, Italy

President: M. Leonardi

\section{Congress}

September 13-17, 1988

Wurzburg, Germany

President: M. Nadjmi

\section{Congress}

20th Anniversary of the ESNR

July 2-6, 1989

Paris, France

President: E.A. Cabanis

\section{Congress}

October 8-13, 1991

Zurich, Switzerland

President: A. Valavanis

\section{Congress}

September 8-12, 1992

Stockholm, Sweden

President: K. Ericson

\section{Congress}

September 8-12, 1993

Bruges, Belgium

Presidents: D. Balériaux - B. Appel

XX Congress

25th Anniversary of the ESNR

June 14-18, 1994

Nancy, France, President: L. Picard

\section{Congress}

September 20-23, 1995

Budapest, Hungary

President: J. Kenéz

XXII Congress

September 17-21, 1996

Milan, Italy

President: G. Scotti

\section{Congress}

September 16-20, 1997

Oxford, United Kingdom

President: J.V. Byrne

XXIV Congress

September 23-26, 1998

Lisbon, Portugal

President: A. Goulão

XXV Congress

September 7-11, 1999

Vienna Austria

President: E.Schindler

XXVI Congress

September 10-13, 2000

Oslo, Norway

President: P.H. Nakstad

XXVII Congress

joint meeting with the ESHNR

September 13-16, 2001

Ancona, Italy

President: U. Salvolini

\section{Congress}

September 11-14, 2003

Istanbul, Turkey

President: E. T. Tali

XXIX Congress

September 8-11, 2004

Aachen, Germany

President: A. Thron

\section{Congress}

September 15-18, 2005

Barcelona, Spain

President: J. Ruscalleda 


\section{Congress}

September 13-16, 2006

Geneva, Switzerland

President: D. Rüfenacht

\section{Future Congresses}

XXXII Congress

September 20-23, 2007

Genova, Italy

President: P. Tortori Donati

\section{Congress}

September 25-28, 2008

Krakow, Poland

President: M. Sasiadek

XXXIV Congress

September 2009

Athens, Greece

President: A Gouliamos

European Course

in Paediatric Neuroradiology

\section{Past Courses}

\section{Course}

October 6-11,1995

Marseille, France

President: Ch. Raybaud

\section{Course}

April 15-18, 1999

Rapallo, (Genova) Italy

President: P. Tortori Donati

\section{Course}

October 8-12, 2003

Brienz, Switzerland

President: E. Martin Fiori

\section{Future Course}

April 16-19, 2008

London, UK

President: Kling Chong

\section{Symposium Neuroradiologicum}

Past Symposiums

I Symposium

1939

Antwerp, Belgium

President: R. Thienpont

\section{Symposium}

1949

Rotterdam, The Netherlands

President: B. G. Ziedses des Plantes

III Symposium

1952

Stockholm, Sweden

President: E. Lindgren

IV Symposium

1955

London, United Kingdom

President: J.D.W. Bull

\section{Symposium}

1957

Brussels, Belgium

President: Donald L. McRae

\section{Symposium}

1961

Rome, Italy

President: G. Ruggiero

\section{Symposium}

1964

New York, USA

President: J. Taveras

\section{Symposium}

September 25-30, 1967

Paris, France

President: H. Fischgold

\section{Symposium}

August 24-29, 1970

Gothenburg, Sweden

President: I. G. Wickbom

\section{Symposium}

March, 10-16, 1974

Punta del Este, Uruguay

President: N. Azambuja
XI Symposium

June 4-10, 1978

Wiesbaden, Germany

President: S. Wende

XII Symposium

October 10-16, 1982

Washington D.C., USA

President: G. di Chiro

\section{Symposium}

June 23-28, 1986

Stockholm, Sweden

President: T. Greitz

XIV Symposium

June 17-23, 1990

London, United Kingdom

President: G. du Boulay

\section{Symposium}

Sept. 25-Oct. 1, 1994

Kumamoto, Japan

President: M. Takahashi

\section{Symposium}

May 15-17, 1998

Philadelphia, USA

President: S.K. Hilal,

Vice President: S.A. Kiefferx

\section{Symposium}

August 18-23, 2002

Paris, France

President: L. Picard

XVIII Symposium

March 19-24, 2006

Adelaide, Australia

President: M. R. Sage

Future Symposia

XIX Symposium

2010

Bologna, Italy

President: M. Leonardi 


\section{The European Course in Neuroradiology}

The European Course in Neuroradiology has been a story of success ever since the first course in Toulouse in 1984. More than 500 young neuroradiologists have completed the cycle of three courses over the past 21 years. The ECNR was conceived as a means to create a common and shared culture, common meeting points and a common standard of knowledge. The form that was adopted and used for the coming 6 cycles, each consisting of three courses, included the major bodies of knowledge as described by the headlines; intracranial nervous system, the spine and spinal cord and the base of the skull, maxillofacial and head and neck neuroradiology.

\section{Past Courses}

First Cycle

First Course

Intracranial Nervous System

September 9-13, 1984, Toulouse

Organization: C. Manelfe

\section{Second Cycle}

First Course

Intracranial Nervous System

September 2-5, 1987, Barcelona

Organization: J. Ruscalleda

\section{Third Cycle}

First Course

Intracranial Nervous System

September 4-8, 1990, Milan

Organization: G. Scotti

\author{
Second Course \\ Skull Base \\ September 2-5, 1985, Ancona \\ Organization: U. Salvolini
}

\author{
Second Course \\ Skull Base \\ August 22-26, 1988, London \\ Organization: B. Kendall
}

\author{
Second Course \\ Skull Base \\ July 9-13, 1991, Frankfurt \\ Organization: H. Hacker in \\ conjunction with: 1st ESNR \\ Course in Interventional \\ Neuroradiology \\ Organization: J. Moret \\ and A. Valavanis
}

\section{Fourth Cycle \\ First Course}

Intracranial Nervous System

May 28-June 1, 1993, Algarve

Organization: A. Goulao

\section{Fifth Cycle}

\section{First Course}

Intracranial Nervous System

May 18-22, 1996, Tylösand

Organization: K. Ericson

\section{Sixth Cycle \\ First Course \\ Intracranial Nervous System \\ June 11-16, 1999, Illetes \\ Organization: L. Pons}

\section{Second Course \\ Skull Base \\ June 9-13, 1994, Maastricht \\ Organization: J. Valk, J. Wilmink}

\author{
Second Course \\ Skull Base \\ May 31-June 4, 1997, Leuven \\ Organization: G. Wilms
}

\author{
Second Course \\ Skull Base \\ May 19-24, 2000, Opio \\ Organization: P. Lasjaunias
}

\section{Third Course \\ Spine and Spinal Cord \\ September 8-11, 1986, Brussels \\ Organization: D. Balériaux}

\section{Third Course}

Spine and Spinal Cord

May 7-11, 1989, Lund

Organization: S. Cronqvist

\section{Third Course}

Spine and Spinal Cord

May 15-19, 1992, Corsica

Organization: Ch. Raybaud

\section{Third Course}

Spine and Spinal Cord

May 26-30, 1995, Prague

Organization: P. Kalvach

\section{Third Course}

Spine and Spinal Cord

May 22-27, 1998, Bologna

Organization: M. Leonardi

\section{Third Course}

Spine and Spinal Cord

May 12-17, 2001, Antalya

Organization: E. T. Tali 


\section{ECNR - the new concept}

The ongoing work within the ESNR, through the established European Board of Neuroradiology, is focused on establishing a European certification in Neuroradiology. This work will initially have to concentrate on the development of European standards of training in neuroradiology. One of the corner stones of such a program is an assessable and lasting common training program. Specialist training in Europe is officially monitored and regulated by UEMS, a Brussels based organisation of representatives for established medical specialities. UEMS defines three arms of specialist training; knowledge, competence and attitude. The mandate of UEMS can be defined as an administrative way of establishing a European certification in a medical speciality, i.e. Neuroradiology. An alternative way of establishing European standards of training in neuroradiology would be using an academic way. An Academic certification can be designed as a Master of Medical Sciences with major in Neuroradiology. Such programs can be established locally, e.g. in Barcelona and Stockholm. Although academic Master programs may have a very high standard of training, they do not provide any official license to practice neuroradiology in any European country.

The recommendations of UEMS, as well as any Master program, include theoretical training in key subjects for a certain speciality. Acceptable theoretical training must include defined curricula as well as examinations. Furthermore, it should be possible to complete a medical speciality or a Master program in two years. Harmonisation with these rules and regulations are the very strong reasons to change the format of ECNR to include four courses given over a two- year-cycle. It was felt that this would also be a good time to change the topics of ECNR to reflect a wider scope of neuroradiology from a standpoint of knowledge rather than that of practice. This change will increase our possibility to include anatomists, clinicians and interventionalists in the faculties.

The following topics have been chosen, each to be covered in six full days of lectures and work shops:

- Anatomy, congenital malformations and genetics.

- Trauma, Infection, Inflammation and Degenerative Disease

- Tumours of the Brain and Spinal Canal

- Vascular Disease of the Brain and Spinal Canal

\section{Seventh Cycle \\ Scientific Director: Guido Wilms (Leuven)}

\section{First Course}

Embryology, Anatomy, Malformations

Crieff, October 4-11, 2002

Local Director: Wendy J. Taylor

\section{Second Course}

Tumours of the CNS

Riga, April 11-18, 2003

Local Director: Cosma Andreula

\section{Third Course}

Vascular Disease of the CNS

Malta, October, 24-30, 2003

Local Director: Athanassios Gouliamos

\section{Fourth Course}

Trauma and Degenerative Disease of the CNS

Riga, April 23-27, 2004

Local Director: Johan Van Goethem

\section{Ninth Cycle \\ Scientific Director: Ernst-Wilhelm Radü}

\section{Eighth Cycle \\ Scientific Director: Ernst-Wilhelm Radü}

\author{
First Course \\ Embryology/Anatomy/Malformations/Genetics \\ Basel, October 22-26, 2004
}

\author{
Second Course \\ Tumours of the CNS \\ Basel, March 18-22, 2005
}

\author{
Third Course \\ Vascular Disease of the CNS \\ Basel, October 21-25, 2005
}

\section{Fourth Course}

Trauma and Degenerative Disease of the CNS

Basel, March 10-14, 2006

First Course: Embryology/Anatomy/Malformations/Genetics - Basel, October 20-24, 2006

Second Course: Tumours of the CNS - Basel, March 23-27, 2007

Third Course: Vascular Diseases of the CNS - Basel, September 7-11, 2007

Fourth Course: Trauma/Degenerative Diseases of the CNS - Basel, February 8-12, 2008 


\section{The Refresher Course of the ESNR}

Preceding the annual congress, a one-day long Refresher Course is offered to the members of the Society each year. This new educational activity of the ESNR, initiated in 1987, is conceived to enhance and increase the clinical and biological background of Neuroradiologists; to refresh pertinent anatomic knowledge and to update recent advances in imaging techniques and in the diagnostic management of neurological as well as head and neck diseases.

\section{1st Introductory Course}

September 8, 1987, Udine

1st Refresher Course

October 9, 1991, Zurich

\section{2nd Refresher Course}

September 8, 1992, Stockholm

\section{3rd Refresher Course}

September 8, 1993, Bruges

4th Refresher Course

June 15, 1994, Nancy

5th Advanced Course

September 20, 1995, Budapest

6th Advanced Course

September 18, 1996, Milan

7th Advanced Course

September 17, 1997, Oxford

8th Advanced Course

September 23, 1998, Lisbon

9th Advanced Course

September 7, 1999, Vienna

10th Advanced Course

September 10, 2000, Oslo

11th Advanced Course

September 13, 2001, Ancona

12th Advanced Course

September 11, 2003, Istanbul

13th Advanced Course

September 8, 2004, Aachen

14th Advanced Course

September 15, 2005, Barcelona

15th Advanced Course
Topics: Artificial Intelligence

MRI

Topics: Venous disorders of the brain

Cranial base extension of nasopharyngeal tumors

Cervical spine

Congenital anomalies of the anterior cranial base

Topic: Traumatic brain injury in adults and children

Topic: Neuroradiology of the cerebral fluid spaces and their disorders

Topic: Cerebral functions and their disorders - language and aphasia

Topic: Neuroimaging of the craniocervical junction

Topic: Functional neuroanatomy of motion and vision: the role of the Neuroradiologist, from research to clinical practice.

Topic: Ischaemic Stroke

Topic: Arteriovenous Malformations

Topic: MR in Neuroradiology - Update and State of the Art

Topic: Cerebral Aneurysms

Topic: Advances in Neurosciences

Topic: Foundation in Neuroimaging

Topic: Spine and Spinal Cord

Topic: Neuroaxonal Injury and Degeneration

Topic: Cerebrovascular Diseases 


\section{Neuroradiology}

Neuroradiology, published by Springer Verlag, was founded as the official organ of the European Society of Neuroradiology in 1970. Since 1981, Neuroradiology is also the official organ of the Japanese Neuroradiological Society.

The Founding Editors of the journal are:

M.M. Schechter, New York (deceased)

A. Wackenheim, Strasbourg (deceased)

S. Wende, Mainz (deceased)

\section{Past Editors-in-Chief}

1970-1974

M.M. Schechter, New York

A. Wackenheim, Strasbourg

S. Wende, Mainz

1974-1980

G. du Boulay, London

M.M. Schechter, New York

A. Wackenheim, Strasbourg

S. Wende, Mainz

\section{1-1983}

G. du Boulay, London

T.P. Naidich, Chicago

M.M. Schechter, New York

A. Wackenheim, Strasbourg

S. Wende, Mainz

\section{3-1988}

G. du Boulay (Chairman), London

T.P. Naidich, Chicago

M. Takahashi, Kumamoto

A. Wackenheim, Strasbourg

M.M. Schechter (Emeritus), New York

\section{8-1991}

G. du Boulay, London

T.P. Naidich, Chicago

M. Takahashi, Kumamoto

A. Valavanis, Zurich

A. Wackenheim, Strasbourg

S. Wende, Mainz

R.A. Zimmerman, Philadelphia

\section{1-1993}

T.P. Naidich (Chairman), Miami

I. Moseley, London

M. Takahashi, Kumamoto

A. Valavanis, Zurich

C. Manelfe, Toulouse

R.A. Zimmerman, Philadelphia

\section{4-2004}

I. Moseley (Chairman), London

C. Manelfe, Toulouse

M. Takahashi, Kumamoto

A. Valavanis, Zurich

R.A. Zimmerman, Philadelphia

ESNR Editors:

D. Balériaux, Bruxelles

C. Andreula, Bari

\section{4-2006}

J. V. Byrne (Chairman), Oxford

P. Demaerel, Leuven

O. Flodmark, Stockholm

G. Schroth, Bern

R. Sellar, Edinburgh

M. Takahashi, Kumamoto

\section{The Board of Editors-in-Chief}

2006

Editor-in-Chief: J. V. Byrne (Chairman), Oxford

Section Editors:

J.W.Casselman, Brugge (Head \& Neck Radiology)

P.Demaerel, Leuven (Diagnostic Neuroradiology)

C.Raybaud, Toronto (Paediatric Neuroradiology)

R.Sellar, Edinburgh (Interventional Neuroradiology)

S.Sunaert, Leuven (Functional and Isotope Neuroradiol.)

Y.Korogi, Fukuoka (Japan)

H.R.Jäger, London (ESNR) 